\title{
Rethinking international financial centres through the politics of territory: Renminbi internationalisation in London's financial district
}

\author{
Sarah Hall \\ School of Geography \\ University of Nottingham \\ University Park \\ Nottingham NG7 2RD \\ Sarah.hall@nottingham.ac.uk \\ +44 (0)1158468404
}

September 2016

\section{0 words}

This paper revisits canonical thinking on international financial centres (IFCs) that understands them as being primarily sustained through: market liquidity; economies of competition and cooperation between financial and related professional services; and acting as interpretative nodes within global finance. In contrast, I explore the implications of foregrounding questions of power and politics in the (re)production of IFCs. Drawing on the case of the development of offshore renminbi markets in London's financial district, I argue the state plays a vital, yet comparatively neglected, role in shaping the development and changing nature of international financial centres. In so doing, the paper calls for work in economic geography and cognate social sciences to understand finance as a political as well as an economic, social and cultural relation.

\section{Keywords}

Renminbi internationalisation, City of London, international financial centres, regulation, territorial fix, offshore finance 


\section{Introduction}

In October 2015, the Financial Times carried the headline 'Chinese financial institutions grow closer to the heart of London' (Financial Times, 2015a). The article documented London's rise as the first and leading western offshore centre (beyond mainland China) for financial products and markets denominated in the Chinese currency - the renminbi (RMB). The article was accompanied by a picture of the Chinese flag flying in the centre of London's historic financial district with the financial offices of Canary Wharf in the background. This image clearly symbolises the marked changes the internationalisation of the RMB is currently bringing about within the international financial system. Prior to 2004, RMB denominated trading was not allowed outside China and the RMB had virtually no international influence. Subsequently, the Chinese monetary and financial authorities have pursued a carefully managed policy of internationalisation such that the RMB is now the fifth most-used currency globally for international payments and was selected to join the International Monetary Fund's basked of global reserve currencies in November 2015 (IMF 2015). Nevertheless, the process of internationalisation and associated financial services sector reform within China has not been without its difficulties. Most notably, the uncertainties surrounding the Chinese financial system were demonstrated by the Shanghai stock market crisis in the summer of 2015 in which trading only resumed following state intervention that was estimated to cost more than US\$800 billion of public and private funds (Reuters 2015). Unsurprisingly, there are doubts as to whether such large-scale rescue operations will remain sustainable in the future. 
In this paper, I use the case of the London's development as an offshore RMB centre to revisit work in economic geography and cognate social sciences on the (re)production and development of international financial centres (IFCs). A vibrant literature has developed in this respect through a range of conceptual approaches and empirical research sites. This includes: intensive analysis of the history of leading financial centres in Europe and North America (Cassis, 2010; Kynaston 2012); relational and networked based accounts of the continued dominance of a small number of financial centres, notably New York and London (Beaverstock et al 2000; Faulconbridge 2004; Sassen 2000); and work on the localisation advantages afforded to financial institutions by co-locating within financial centres (Clark and O'Connor 1997; Porteous 1999; Tickell 2000; Thrift 1994). Collectively, this work has refuted claims that information technology and the associated virtualisation of stock exchanges in particular would lead to the 'end of geography' associated with a decreasing importance of IFCs (on which see O'Brien 1992).

This paper uses the case of RMB internationalisation in London to develop a sympathetic critique of this literature, arguing that research needs to better understand the role of the state, and financial and monetary authorities in particular, in shaping the reproduction and development of international financial centres. This is not to say that the state is entirely absent from extant research. For example, much of the early work on the geographies of money and finance and related fields was concerned with understanding the implications of the collapse of the Bretton Woods agreement of pegged exchange rates from the 1970s onwards 
for the governance arrangements of global finance, particularly the potential for a decline in state power within financial markets (Strange 1988; Leyshon 1992; Thrift and Leyshon 1994; Leyshon and Thrift 1997, Leyshon and Tickell 1994).

Furthermore, whilst offshore financial centres are frequently identified in the media as being places beyond state control, research has shown the vital role played by state-led regulation in their creation and reproduction (Hudson, 1998; Roberts 1995; Palan 2006). Despite this work, much of the recent research on IFCs has emphasised the networked properties of the socio-spatial practices of advanced producer service firms (including finance and law firms in particular) that serve to sustain the importance of IFCs as such centres act as interpretative nodes for knowledge creating, reproduction and exchange within such networks (Beaverstock 2002; 2004; Beaverstock et al 2000).

Understanding these inter-IFC firm networks is clearly important given the implications of such connections for, for example, regulatory change following the financial crisis (Wojcik 2013). Moreover, measures of connectivity between financial centres, including inter-firm relations, have become important components in the numerous rankings of financial centres produced in both academic and practitioner communities (Tschoegl, 2000; Choi et al., 2003; Z/Yen 2016). However, in this paper, I use the case of RMB internationalisation to demonstrate how state intervention is vital in creating the conditions under which these financial networks can develop and thrive. In particular, I suggest that foregrounding the role of the state in the (re)production of IFCs demands a shift in the geographical imagination used to study financial centres from its current emphasis on networks and 
relationality to one more sensitive to the territorial qualities of financial centres and the ways in which territories are co-produced through financial networks (see also Budd 1995; Van Meeteren and Bassens 2016). Drawing on the increasing interest in territory in economic geography and beyond (see for example Christophers 2014; Elden 2005; 2010; Sassen 2008), I demonstrate how the territorial construction of London's financial district, understood as the (re)production of the space of London's financial district through state intervention in setting the institutional and regulatory parameters of legitimate financial activity, are vitally important in understanding the development of offshore RMB markets in London.

This argument is important because it shows how work on IFCs can respond to calls for the development of more politically sensitive accounts of the geographies of global finance more generally (Agnew 2009; Hall 2011; Wojcik 2013; Wójcik et al 2016). It also offers the potential to place IFCs more centrally within longstanding debates concerning the relationship between state power, governance and globalisation (Held and McGrew 2002; Thrift and Leyshon 1994; Leyshon and Thrift 1997). In particular, I show how state power remains important, if not increasingly so, within global finance. This has been documented at the level inter-state relations through, for example, work on currency competition within the international monetary system (see Cohen 2015; Eichengreen 2011). This paper offers a complimentary reading of the importance of state power at the less well-understood scale of financial districts that underpin global finance. I develop this argument over four further sections. Next I locate IFCs within broader debates concerning the relationship between networks and territory in economic geography and cognate 
social sciences. The third section of the paper introduces the process of RMB internationalisation and the role of offshore RMB centres within this. In the fourth section I examine how London's financial district served as a 'territorial fix' (Christophers 2014) for state and private sector interests in China and London concerned with RMB internationalisation and the wider development of London as an IFC. I conclude by reflecting on the significance of this analysis for theoretical understandings of the changing political and economic geographies of IFCs, the role of states and regulators within this and the impacts of RMB internationalisation on the wider geographies of the international financial system.

\section{Placing financial centres within the politics of global finance}

Whilst Faulconbridge et al (2007:281) rightly argue that extant work across a range of disciplines fails to provide a 'consistent analytical framework' for explaining the continued importance of a small number of financial centres, common foci have emerged within the interdisciplinary literature on financial centres. As Cassis (2010) notes, the majority of these explanations centre on the identification of external economies of scale available to firms and financial institutions beyond their firm boundaries through being co-located with other, similar actors with whom they can form relations of competition and cooperation. Three such economies of scale and their associated agglomeration benefits are particularly significant. First, successful financial districts are built on highly liquid financial markets (Faulconbridge et al 2007). Second, the clustering of financial firms within financial centres gives rise to 'buzz' between financiers (Storper and Venables 2004). This buzz, built around 
dense inter-personal and inter-firm relations, is important because it facilitates processes of innovation and the production of new financial products by overcoming the knowledge asymmetries between financiers and their clients that are associated with the bespoke qualities of many financial products and services (see Clark and O'Connor 1997). Third, IFCs typically attract the highly skilled labour force that is needed to work in this information rich environment (Beaverstock and Hall 2012). In addition to this work on economies of scale, connections between IFCs have also been widely identified as important factors in explaining the continued importance of a small number of such centres. This includes work on: the so-called NY-LON connection between New York and London (Beaverstock 2004); the changing landscape of European financial centres (Faulconbridge 2004) and emerging and rapidly developing new forms of connectivity such as in Asia (Lai 2012).

Taken together, therefore, the extant literature on IFCs follows the wider development of relational and networked based approaches to the economy (on which see Bathelt and Gluckler 2003; Yeung 2005) to understand them within "a spatially distributed network of money and power, where the global and local processes intermesh and run into each other in a variety of ways" (Wójcik, 2013: 2). However, the relationship between networks and the places and spaces in which they become grounded, interpreted and acted upon is a longstanding concern within economic geography, extending well beyond work on IFCs (Dicken 1994; Scott 1998; Storper 1997). In this paper, I want to suggest that whilst by no means ignoring the territorial basis of IFCs, the relative balance of work on such centres has taken networks and flows of people, knowledge, information and capital as their starting 
point and hence, understandings of how these networks are grounded and reworked in particular places has been comparatively neglected (see Van Meeteren and Bassens 2016). In particular, I am interested in how this focus has meant that the governance of such networks, and particularly the role of the state in such activities, remain overlooked.

A number of interventions, including but not limited to work in finance, provide a valuable way of beginning to develop a more comprehensive understanding of the role of the state in reproducing and maintaining IFCs. In order to do this, I take as my starting point the renewed interest in territory within geography more generally. This work understands territory as a way of making and managing space through legal and other regulatory frameworks (Elden 2005; 2010). When applied to the case of economic geography, this echoes earlier work that is concerned with 'the sets of institutions, rules, and conventions that form the regulatory context of industrial systems, firms, and territories' Dicken and Malmberg 2001: 347) and more recent concerns to understand 'territorial development' within recent work in the global productions literature (Yeung and Coe 2015). This work is important because it signals the importance of attending to the mulitscalar connections implicated in the making of particular territories (see also Amin 1998).

In terms of work on the geographies of finance, this approach has been developed through the longstanding interest in offshore finance that emphasises the ways in 
which offshore space is constructed through the variation of state sovereignty across space (Palan 2006; Roberts 1995; Hudson 1998). Meanwhile, Pike and Pollard (2010:38) argue that the vast literature on financialisation needs to remain attentive to the 'tensions between territorial and relational conceptions of space and place'. Christophers (2014:755) has recently taken this analysis a stage further by examining how "modern capitalism is constantly in the process of enacting territorial fixes: constituting, segmenting, differentiating and extracting value from actively territorialized markets at a range of geographical scales." This provides a valuable extension of Harvey's (1982) understanding of spatial fixes by demonstrating how capitalism seeks to overcome its crisis prone tendencies not only through spatial expansion but also through the remaking of space through regulatory and other political interventions. In what follows, I examine the role of the state in using IFCs as 'territorial fixes' within the international financial system through regulatory changes that aim to (re)produce their institutional arrangements of rules, informal customs and practices.

I illustrate this approach through focusing on how London's financial district was used as a territorial fix for financial and monetary authorities in both China and London in its development as the first and leading western offshore RMB centre from 2011 onwards. The analysis reports on original empirical research conducted in London and Beijing into London's development as an offshore RMB centre since 2011 and the development of an RMB bond market in London in particular. The research involved two stages. First, desk based reviews were conducted into: official 
statistics on the development of RMB services and functions in London from both London (including the National Office for Statistics, City of London and HM Treasury) and China (through the State Administration of Foreign Exchange (SAFE)); and analysis of press reports, Government press releases in China and London as they relate to renminbi internationalisation and the development of RMB bond markets in London. Second, thirty semi-structured interviews were conducted in London and Beijing between September 2014 and June 2015. Interviews were conducted with financiers working in a range of RMB product areas in London and Beijing working in Chinese banks and non-Chinese owned financial institutions, lawyers working on $\mathrm{RMB}$ products in London, regulators and market commentators concerned with advancing understanding of RMB internationalisation and London's role within this in London and Beijing. Interviews were conducted in English and lasted between thirty minutes and two and a half hours. All interviews were recorded and transcribed in full before being coded following grounded theory with key themes being identified to shape the coding process.

\section{Placing London within RMB internationalisation}

In order to understand how the place specific socio-spatial practices within London's financial district operated alongside its territorial qualities in its development as an offshore RMB centre, it is important to begin by situating London within the wider geographies of RMB internationalisation. It is not easy to give a precise start date for RMB internationalisation as it has unfolded incrementally through a series of policy changes initiated by the political and financial authorities in Beijing (Chen and 
Cheung 2011; Walter and Howie 2012). However, the early 2000s marked an important period of financial policy liberalisation (SWIFT 2011), building on the broader internationalisation of the Chinese economy (see Yeung and Liu 2008). For example, in 2006, the study group within the People's Bank of China published a report entitled 'The timing, path and strategies of RMB internationalization' that gave significant impetus to currency internationalisation (PBOC study group 2006). This report argued that currency internationalisation could enhance the competitiveness of the Chinese economy. Moreover, the financial crisis of 2008 provided additional motivation for the Chinese government to support RMB internationalisation as it sought to reduce China's reliance on the US dollar in trade relationships (Walter and Howie 2012; Zhang 2009).

Building on these early developments, RMB internationalisation can be broken down into three phases, following the initial period of policy liberalisation in the early 2000s (see figure 1). Each of these phases involved the development of distinctive geographies of RMB internationalisation associated with processes of territorialisation. These financial geographies have been shaped significantly by regulatory and broader state intervention by financial authorities in Beijing in order to address particular limitations associated with the wider RMB internationalisation project.

As figure one shows, following initial policy liberalisation, internationalisation focused on the RMB as a form of regional trade money through a gradual expansion in the ways in which the RMB could be used to settle trade (Eichengreen and Kawai 
2014; ASIFMA 2014). The Chinese monetary authorities used a number of initiatives to facilitate this. Most notably, in July 2009 a pilot RMB cross border trade settlement program was launched. This program allowed importers in Shanghai and four selected cities in Guangdong (Guangzhou, Shenzhen, Zhuhai and Dongguan) to settle cross-border trades with Hong Kong, Macau and ASEAN countries in RMB. Up until this point, trade was typically settled in US dollars or Euros, leading to significant transaction and hedging costs for Chinese firms when dealing in foreign currencies. The scheme was expanded in July 2010 to allow settlement in RMB for firms operating in a much broader range of locations in China (including Beijing and twelve provinces) with any country globally, thereby marking a significant geographical expansion of RMB internationalisation beyond south east Asia. Following this, the proportion of China's trade settled in RMB has grown from $7 \%$ in 2011 to $14 \%$ in 2013 (ASIFMA 2014).

[insert figure 1 here]

Whilst trade money was the primary focus of the initial stages RMB internationalisation, by the late 2000s, the early stages of the next phase of RMB internationalisation were being developed. This focused on internationalisation based around the RMB as a form of investment money - an initiative that was aimed at overcoming some of the problems that were emerging following the growing use of RMB in global trade. In particular, concerns were emerging that companies trading with China were converting their RMB back into their domestic currency and hence not reinvesting in mainland China (HSBC 2013). In response, a number of 
policy changes were made. Of particular importance is the RMB Qualified Foreign Institutional Investor Program (RQFII) that was announced in 2011. This program allowed licensed investors to use RMB held offshore to invest in China, through the Shanghai and Shenzhen stock exchanges, in financial products including shares, bonds, securities and stock index futures. Initially, all investments into the Chinese mainland through this scheme had to be made through funds based in Hong Kong. However, from 2013 onwards the geography of this was expanded, initially permitting investment through Singapore based funds. In 2014, further internationalisation occurred when London was given an RQFIl quota of RMB80bn.

[insert table 1 here]

It is at this stage that the distinctive spatial footprint of RMB internationalisation begins to emerge as the Chinese financial authorities have sought to facilitate RMB internationalisation whilst managing a gradual process of capital account liberalisation and maintaining control of exchange rates (He and McCauley 2010). These twin policy objectives have resulted in a distinctive geography of regulatory reform based around a separation between onshore RMB markets (using the currency designation CNY) and offshore markets (understood as those outside of mainland China) including Hong Kong (with the currency designation $\mathrm{CNH}$ ). Interest and exchange rate controls remain in onshore RMB markets whilst these have been liberalised in offshore RMB markets (ASIFMA 2014). This distinction echoes Palan's (2006, xix) argument that offshore financial space is constructed through processes of re-regulation as it 'becomes an embedded dimension of contemporary 
statehood'. In the case of RMB internationalisation, offshore financial space is organised through a small number of offshore financial centres. Echoing the use of Hong Kong as an experimental site for the reform and internationalisation of the Chinese economy more generally (Chen and Cheung 2011), Hong Kong became the first such centre in mid 2010 (Walter and Howie 2012). Since then, a small number of other financial centres including Singapore, Taiwan and London have developed significant RMB financial markets (Standard Chartered 2014). These offshore RMB centres can be defined as a financial centre "outside [mainland] China that conducts a wide variety of financial services denominated in RMB" (ASIFMA 2014, 20) that connects with onshore financial services in mainland China (Subacchi and Huang 2012).

As table 1 shows, in addition to holding an RQFII quota, these centres host a designated RMB clearing bank, hold sizable (although varying) RMB deposits and have seen the development of a range of RMB markets. These centres are supported by a number of offshore financial RMB hubs (such as Paris and Frankfurt) that access mainland China through the offshore RMB centres (Subacchi and Huang 2012). Hong Kong remains the largest offshore RMB Centre and has been the most widely studied to date (see Fung and Yau 2012). However, the case of the development of London as an offshore RMB centre raises important questions about how and why it became the first western such centre and the implications of this for the possible future trajectories of RMB internationalisation and understandings of IFCs more generally. 
Territorial fixes and the (re)making of regulatory space in London's development as an offshore RMB centre

A central insight of the recent resurgence of interest in territory has been its dynamic qualities such that, in the case of the economy, it is constantly in the process of being refigured to achieve capital accumulation therefore serving as what Christophers (2014:745) terms a 'market making economic technology'. Drawing on this understanding of territory, in what follows I being by examining why London was identified as having the potential to be developed as the first western offshore RMB centre before turning to how this was achieved through state interventions by both China and the UK that served to use London as, in Christophers (2014) terms, a 'territorial fix' within RMB internationalisation.

Legitimising London as the 'western offshore RMB centre of choice'

By taking the territorial qualities of London's financial district as my starting point, table 2 specifies three sets of institutions that account for why London was identified by the Chinese monetary authorities as the location for the first western offshore $\mathrm{RMB}$ centre and how this was supported by both the state and private sector in London. First, London specific conventions, understood as the socio-cultural norms that structure and shape what counts as desirable and legitimate financial activity in the City were instrumental for both Chinese monetary authorities and policy makers and the private sector financial services community in the UK. In particular, the

\footnotetext{
${ }^{1}$ Wenjian Fang, Chief executive Bank of China, London, cited in Euromoney 2014
} 
relationship between the temporal and geographical specificity of these conventions as they operated in the late 2000s in the wake of the 2007-8 financial crisis and the trajectory of RMB internationalisation needs to be understood.

Beginning with the creation of new financial markets and products that are clearly necessary if RMB finance is to be developed in London, following the $2007-8$ crisis there was a concern within both practitioner and policy making circles concerning the potential for the crisis to threaten London's position as a, if not, the leading IFC (Hall, 2009). As Table 2 shows, these concerns meant that London's financial sector community, with the support of the UK Government, was particularly open to experimentation and the associated development of new forms of financial markets 'in an effort to maintain it's position as the leading international financial centre globally' (Financial journalist, China specialist, London, February 2015). This is also reflected in comments from senior managers in leading investment banks made at the time

'HSBC is fully committed and uniquely positioned to support the internationalisation of the RMB for the benefit of China and the global economy. This initiative reinforces London as a leading global financial centre' (Spencer Lake - Co-Head of Global Markets, HSBC, cited City of London/Bourse Consult 2014).

[insert table 2 here] 
This is related to the second set of conventions that were important in London's development as an offshore RMB centre, which can be summarised as its 'genuine and deep international disposition' as a junior Chinese banker put it to me in April 2015. This reflects the fact that London, in contrast to New York, has always relied on international financial services for its development, given the relatively small size of its potential domestic market (Kynaston 2012). In particular, as Table 2 shows, the British Government was vital in facilitating this because under Prime Minister David Cameron, it was prepared to overlook concerns over China's human rights record in order to facilitate economic, and particularly financial, links with China in order to secure economic development through the continued dominance of London as an IFC (The Guardian 2015). Indeed, the Chancellor of the Exchequer at the time, George Osborne, has been described as a Sinophile who was particularly keen to develop bilateral economic agreements with China (Financial Times 2015b).

The third set of conventions that are important in the identification of London as the chosen location for the first western offshore RMB centre lies in its close relational proximity with both Hong Kong (the first offshore RMB centre) and monetary authorities in Beijing, as shown in table 2. These connections are important because 'they afforded a degree of comfort for financial regulators in Beijing that they understood how London worked and would respond to their requests and at least an understanding of how Chinese finance might operate within London's finance community through the close colonial based relations with Hong Kong', as a capital markets lawyer working on RMB bonds put it in March 2015. This builds on the wider importance of this relational proximity for Chinese financial geographies more 
generally. For example, Lai (2011) has argued that London served as a preferred 'learning partner' for the restructuring of the Chinese banking system because of the close personal and social networks between senior policymakers in Beijing and their UK counterparts.

However, whilst these conventions within London and the role of state and policymaker support for them from both Beijing and the UK clearly played an important role in the legitimation of London as the first western offshore RMB centre, as Table 2 shows, it is important to note that more standard institutional attributes identified in the literature on the success of London as an IFC and the external economies of scale that is offers were also important. In this respect, London's time zone, facilitating 24 hour trading with overseas counterparts, its historic reliance on foreign exchange markets and its deep and dense pool of highly skilled labour have all been identified in the policy literature surrounding RMB internationalisation, echoing the considerable literature in geography that has developed to explain London's continued importance as an international financial centre (Clifford Chance 2012; Thrift 1994; see also table 1.) For example the importance of time zones in determining the location and relative success of offshore RMB centres is reflected in the announcement made by the Bank of China in Hong Kong in August 2014 that from 1 October 2014 it would extend the hours it offered RMB clearing services in Hong Kong in order to cover the time zones of Europe and America as well as Asia (Bank of China 2014).

Finally, the third dimension of London's institutional landscape that was important in facilitating its initial development as an offshore RMB centre was its approach to 
regulation, and particularly the use of regulatory changes to facilitate the development of offshore markets historically through the development Eurodollar markets in the 1960s and 70s (Subacchi and Huang 2012). Crucial to the development of Euro bond markets in London was the combination of regulatory change and the ways in which financial institutions sought to work within this changing environment whilst also shaping it in ways most advantageous to their own ends (in other words, remaking the territorial qualities of London's financial district at the time (Burn 1999; Schenk 1999). There are clear differences between the Eurodollar markets and offshore RMB centres, not least the far more interventionist role played by the Chinese state in the latter compared with the US government in the former, such that financial authorities in London are responding to regulations made at a distance, rather than shaping the process themselves as was the case in Eurodollar markets (Subacchi 2014). However, the existence of euro-dollar markets in London was taken as evidence of London's ability and willingness to make regulatory changes to develop offshore markets, reflecting its wider expertise in foreign exchange markets as shown in Table 2.

Taken together, these institutional dimensions of London's financial district explain why it was selected as the first offshore RMB centre. They also show how these territorial qualities of London as an IFC are tied into relations with both the Chinese and British states, particularly through financial and monetary authorities. However, in order to understand how London subsequently developed as an offshore RMB centre, it is necessary to examine how the territorial qualities of London's financial 
district were (re)produced through regulatory change initiated by both China and the UK.

Territorial fixes in the making of offshore RMB markets in London

Three sets of relations, that combine multi scalar relations beyond the boundaries of London's financial district, are particularly important in understanding how financial space in London was (re)produced in an effort to use it to provide a territorial fix for monetary authorities and the financial services sector concerned with the development of RMB financial markets: first, Annual UK-China Economic and Financial Dialogues; second the City of London Initiative on London as a centre for RMB business; and third, the London-Hong Kong RMB forum. Below I consider each of these in turn.

Beginning with the annual UK-China Economic and Financial Dialogues these have taken place primarily at the level of deputy prime minister annual since 2007 . The significance of these dialogues is two fold. At one level, they serve as a platform to announce key regulatory changes, predominately from Beijing but also from the UK's monetary authorities, that have facilitated the development of RMB markets in London. However, at another level, they also serve an important discursive role in the careful performance of close economic and financial relations between the UK and China that are used by both sides to demonstrate their commitment to the place of London within RMB internationalisation. The fifth and sixth dialogues are 
particularly important because these meetings signalled a marked acceleration in the pace and scale of London's development as an offshore RMB centre (see figure 2).

[insert figure 2 here]

The fifth UK-China Economic and financial dialogue was held in Beijing in October 2013 between the Chinese Vice Premier Ma Kai and the UK's Chancellor of the Exchequer George Osborne. At this meeting, a joint commitment was made to facilitate liquidity of RMB in London building on the currency swap arrangement in 2013 between the Bank of England and the People's Bank of China. ${ }^{2}$ It was also announced that UK institutions would be given licenses within the RQFII (Renminbi Qualified Foreign Institutional Investor) scheme before the end of 2013 with an initial UK quota of RMB 80billion issued to London in October 2013. This is significant within the wider project of RMB internationalisation and the place of London within it because the scheme allows foreign investors to invest offshore RMB raised in designated financial centres into Chinese securities for the first time and London was the first such centre outside greater China to be issued with a quota.

The UK's monetary authorities sought to respond to this demonstration of Beijing's commitment to London through their own regulatory changes. Most notably, it was agreed that the Bank of England would agree to consider applications from Chinese

\footnotetext{
${ }^{2}$ See the combined policy outcomes of the $5^{\text {th }}$ China-UK Economic and Finance dialogue available from https://www.gov.uk/government/uploads/system/uploads/attachment_data/file/25 0003/UK_Chinese_EFD_outcomes_paper.pdf.
} 
Banks to open branches rather than subsidiaries in the UK. Up until this point, the development of Chinese banks in London was characterised by a cautious approach, following the 2007-8 financial crisis, with only subsidiaries permitted to open with their associated higher capital and liquidity requirements. However, this met with significant concern from the Chinese banking industry, echoing research that has demonstrated how firms from emerging markets such as China seek out internationalisation opportunities in part to overcome regulatory constraints in their home market (Luo and Tung 2007). For example, in a letter to HM Treasury in 2012 the Association of Foreign Banks argued that 'they [Chinese banks] are finding it increasingly difficult to operate in the UK under the current regulatory environment'. This changed in June 2014 when it was announced that Industrial and Commercial Bank of China would be given a full banking licence in London by the end of 2014 . The Chinese bank ICBC welcomed this in their annual report arguing that

\footnotetext{
'The most welcome [outcome of the Fifth Dialogue] was the announcement in October by the Chancellor of the Exchequer that the Prudential Regulation Authority will allow our Chinese banks to establish branches in London as soon as the regulatory details have been agreed. This is something for which we have campaigned for some time. In ICBC (London) plc, as a locally constituted subsidiary, we are constrained in our lending by the amount of our local capital.' (ICBC London 2013, 5).
}

Building on these developments, at the sixth dialogue held in London in September 2014 , it was recognised that 'the London RMB market [...] is at the forefront of RMB 
business among European countries' ${ }^{3}$ This position was reflected in a number of important announcements concerning regulatory changes aimed at enhancing London's role in RMB internationalisation. Most notably in June 2014 China Construction Bank was named as the renminbi clearing bank in London. As in previous meetings, the importance of this announcement from Beijing was reflected in regulatory changes made in London in order to take advantage of Beijing's continued commitment to London. For example, it was agreed that the Financial Conduct Authority's Approved Persons Regime for asset management and other regulated activity (a de facto register of financiers who are eligible to offer financial advice in the UK) did not include a nationality restriction and hence, Chinese finance professionals would be welcome in the City. Meanwhile, in terms of bonds, it was announced that China Construction Bank intended to issue an RMB bond in London and the UK government announced its intention to issue a RMB denominated bond in London. As a result of these changes, London has rapidly risen to being widely recognised as the leading western offshore RMB centre. For example, by the end of $2013,62 \%$ of all RMB trading conducted outside China and Hong Kong took place in London and the City handles nearly $30 \%$ of all RMB foreign exchange trading (FSTIB 2014).

The commitment of the UK Government under David Cameron and George Osborne to support London's development as an offshore RMB centre is further

\footnotetext{
${ }^{3}$ See the combined policy outcomes of the $6^{\text {th }}$ China-UK Economic and Finance dialogue available from https://www.gov.uk/government/uploads/system/uploads/attachment_data/file/35 4137/UK-China_policy_outcomes.pdf,
} 
demonstrated by the UK government becoming the first western country to issue debt in RMB when it raised 3bn RMB in 2014 in what was the largest ever RMB bond (Moore and Noble 2014). Whilst the issuance itself is comparatively small, it is symbolically important for RMB internationalisation generally but also for demonstrating the UK Government's commitment to developing London as an offshore RMB centre. It is also was indicative of the diversification of investor origins within RMB bond markets with $57 \%$ of investors being Asian and $43 \%$ European (Li 2014).

The remaking of London's territorial space through offshore RMB finance has not been limited to bilateral state relations. London's monetary authorities have also sought to develop London's RMB offshore financial centre credentials, most notably through the creation in April 2012 of the City of London Initiative on London as a Centre for RMB business. This initiative aims 'to consider practical measures to support the development of London as a centre for RMB business' as well as advising HMTreasury on the issues facing London in its development as an RMB centre. Following work on the relations of both competition and cooperation emphasised in much of the research on IFCs in economic geography and the relational proximity between London and greater China more generally, this initiative was also designed to learn from Hong Kong regulators about their experience of developing an RMB centre (see for example City of London/Bourse Consult 2014). To this end, members of the initiative are representatives from leading financial institutions that have offices in London and Hong Kong including Bank of China (UK), HSBC, China Construction Bank (UK) and Barclays. This membership reveals the ways in which 
London sought to develop its expertise in RMB business by drawing on its historic strengths as an international financial with strong links to Hong Kong, fostered through private sector collaboration amongst banks and financial service firms. The Initiative is based on the assumption that these corporate networks can act as pipelines (Bathelt et al 2004) of knowledge sharing and learning such that the corporate experiences of Hong Kong's development as the first and leading offshore $\mathrm{RMB}$ centre can be used to inform London's development.

Indeed, the combination of private sector and state support that underpins London's development as an RMB centre is further evidenced by the London-Hong Kong RMB forum that has met three times in order to raise awareness of RMB markets amongst financial market participants since its foundation in May 2012. This forum involves meetings between UK treasury officials, the Hong Kong Monetary Authority and representatives of banks and financial institutions involved in RMB markets in London and Hong Kong (see, for example, HKMA 2013). The purpose of these meetings is to share information between firms in Hong Kong and London as well as ensure that policy makers and regulators are aware of their requirements. For example, the Bank of England and the Hong Kong Monetary Authority typically act as facilitators at these meetings.

These developments show the strong commitment of policymakers and regulators in both Beijing and London to using the remaking of financial space through regulatory change in London's financial district as a way of facilitating the development of London as an offshore RMB centre. However, it is important to note that significant 
concerns exist surrounding the on going development of London's RMB activities. The most high profile of these has been how the Brexit vote in the UK's referendum on EU membership in June 2015 may affect China's commitment to London as its western offshore centre of choice (South China Morning Post, 2016). Meanwhile, there are indications that the new Prime Minister installed after this vote, Theresa May, is less concerned with fostering relations with China in the name of economic development than her predecessor (BBC 2016). Moreover, prior to the 2015 referendum there was evidence that London's development as an offshore RMB centre was not without its problems. For example, within Europe it was facing competition from a number of centres, particularly Luxembourg (Strauss 2014); the much heralded Chinese bank branches had not been fully integrated into London's financial district (Hall 2015) and the RQFIl quota remained significantly under utilised (SWIFT 2014). These developments clearly remind us that the process of RMB internationalisation, and the development of offshore RMB centres within this, is not straightforward or necessarily linear in nature. However, they also signal the continued role of inter-state relations in shaping this process in ways that echo the wider arguments made in this paper.

\section{Conclusions}

$\mathrm{RMB}$ internationalisation has been identified as the most important process shaping the international financial system since the creation of the Euro (Deutsche Bank 2014). However, academic work in the area remains focused on the potential outcomes of such a process including: the possibility of the RMB challenging the US 
dollar as a new global reserve currency (Cohen 2012; Lee 2014); the relationship between currency internationalisation and the 'opening up' of the Chinese economy (Dobson and Masson 2009); and the changing financial geographies of China (Lim 2010; Wójcik and Camilleri 2013). As such relatively little is known about the distinctive geography of RMB internationalisation as it develops through a unique network of offshore RMB centres. Addressing this oversight, this paper has sought to place RMB internationalisation more centrally within scholarship on the geographies of money and finance, and work on IFCs in particular. However, rather than examining RMB internationalisation through its heartlands, notably Hong Kong, or the debates within mainstream economics concerning the RMB's potential to become the global reserve currency, the paper has taken inspiration from Burawoy's (1998) work on the extended case method to examine RMB internationalisation through the less well studied case of London's development as an offshore RMB centre. In so doing, the analysis has shown that by examining a relatively new process (RMB internationalisation) within a more familiar geographical setting (London's financial district) important theoretical and empirical insights can be developed into RMB internationalisation and the role and nature of financial centres within this.

Theoretically, I have argued that London's development as the first western offshore RMB centre offers a sympathetic critique of the recent tendency to understand IFCs through networked geographical imaginations. This work has done much to helps us understand the relations between IFCs, emphasising how these are mediated through finance and related professional service firms. However, the case of RMB 
internationalisation calls for a shift in these geographical imaginations to examine the territorial qualities and reproduction of IFCs. In particular, I have emphasised the role of the state, and monetary and financial authorities in particular, as they seek to use regulatory changes as a way of using IFCs as a 'territorial fix' to meet their political and economic objectives within the international financial system. However, rather than dismissing the importance of financial networks between IFCs, this approach adopts a multi scalar reading of territory and is concerned with a longstanding set of debates in economic geography and the wider social sciences concerning the co-constitutive relationship between territories and networks and the ways in which territory itself is remade in this process (see Sassen 2008; Dicken et al 2001 for example). I have argued that, in the case of RMB internationalisation, London's financial district offered precisely such a territorial fix in Christophers' (2014) terms or what Elden (2010) terms a 'political technology' that combines both territorial and networked understandings of London. On the one hand, for Chinese monetary authorities, London served as a financial centre capable of meeting their objectives of furthering RMB internationalisation into Europe. Meanwhile, for their UK counterparts, making regulatory changes to support RMB internationalisation in London was undertaken as part of wider efforts to maintain London's position as an IFC in the wake of the 2007-8 financial crisis within a wider political concern to nurture close relationships with China in the hope that they would foster economic growth more generally.

In some ways, the emphasis on the state that emerges in the case of RMB internationalisation may seem rather unsurprising given the nature of the Chinese 
political economy. However, I would suggest that this is analytically useful since the case of RMB internationalisation can serve as an accentuated case to demonstrate the importance of attending to the role of state actors, both within and beyond IFCs in facilitating and shaping their (re)production more generally. In particular, the different institutions and conventions shaped by state intervention within London's RMB markets identified within this paper (ranging from taken for granted cultural norms to more formal regulatory changes) provide a valuable framework for specifying how state actors shape the territoriality of IFCs. In this sense, finance in this paper can be conceived of as a political relation, alongside the economic, cultural and social relations that have dominated work on IFCs of late. This is important because it demands that questions are asked about in whose interests the state is acting when it shapes IFCs in this way. Indeed, these questions are particularly pertinent in the case of the UK where there is a growing recognition that London's financial services sector enjoys a privileged position within the UK political economy, often at the expense of other regions and industries, particularly as Prime Minister David Cameron and the Chancellor of the Exchequer George Osborne actively pursued closer economic links with China through what The Economist (2015) termed 'The Osborne Doctrine'.

In a more empirical vein, the approach taken in the paper offers a nuanced reading of RMB internationalisation. Here I argue that it is not a straightforward, linear and predictable process that has one predetermined end point, notably the possible development of the RMB as a global reserve currency that has been the focus of much of the academic debate on RMB internationalisation to date. Rather, offshore 
RMB space is being (re)produced in London through the interplay of relations with other IFCs, notably Hong Kong, the place of London's financial district including its accepted socio-economic norms and the territorial qualities of London's financial district as it is (re)produced through regulatory changed initiated by financial authorities in both Beijing and London. How these elements are combined in particular offshore RMB centres and hubs and how they interact with the institutional, political and cultural make up of these places is likely to be important in explaining the future trajectories of RMB internationalisation and its broader role in shaping the continued variegation within the geographies of money and finance.

This analysis is also valuable in terms of demonstrating the changing and increasingly important role of offshore spaces and places within the international financial system. There has been a renewed interest in offshore finance within economic geography and cognate social sciences recently (see for example Clark et al 2015; Wójcik 2013; Haberly and Wójcik 2015). This work has gone beyond earlier research that focused on small, island economies (Roberts 1995). Rather it draws attention to the growing range of offshore activity and a concomitant diversity in the places in which it takes place. Indeed, it is well documented that China's financial system is tied into a series of offshore financial networks (Sharman 2012). The analysis in this paper makes important interventions in this work by complicating the separation between on and offshore finance, revealing the ways in which through relational, place and territorial practices, significant new forms of offshore finance are being (re)produced in established IFCs with important implications for the future trajectory of the international financial system. Such insights are important not only in terms 
of understanding offshore finance in and of itself but also in terms of contributing to a renewed interest in the politics of global finance and the role of financial centres within this.

\section{References}

Agnew J 2009 Money Games: Currencies and Power in the Contemporary World Economy Antipode 41 214-238

ASIFMA 2014 Rmb roadmap Asian Securities Industry and Financial markets association, Hong Kong

Bank of China 2014 BOCHK enhances its RMB clearing services with the longest opening hours globally retrieved from http://www.bochk.com/web/about/press_release/press_release_details.xml? section=about\&level_2=press_release $\&$ fldr_id $=32382 \&$ selFldr $=32382 \&$ pfid $=84$ \&cid=63496, 29/09/14

Bathelt H \& Gluckler J 2003 Toward a relational economic geography. Journal of Economic Geography 3 117-144

Bathelt H, Malmberg A, \& Maskell P 2004 Clusters and knowledge: local buzz, global pipelines and the process of knowledge creation Progress in Human Geography $2831-56$

BBC 2016 Hinkley Point: Theresa May's China calculus 31 July 2016 http://www.bbc.co.uk/news/world-36937511, accessed 26/9/16 
Beaverstock J V 2002 Transnational elites in global cities: British expatriates in

Singapore's financial district Geoforum 33 525-538

Beaverstock J 2004 Managing across borders': knowledge management and

expatriation in professional service legal firms Journal of Economic Geography 4 157-179.

Beaverstock JV, R.G. Smith and P.J. Taylor 2000 World city network: a new metageography? Annals of the Association of American Geographers 90123 34

Beaverstock J V \& Hall S 2012 Competing for talent: global mobility, immigration and the City of London's labour market Cambridge Journal of Regions, Economy and Society 5 271-288

Budd L 1995 Globalisation, territory and strategic alliances in different financial centres Urban Studies 32 345-360

Burawoy M 1998 The extended case method Sociological Theory 16 4-33

Burn G 1999 The state, the City and the Euromarkets Review of International Political Economy 6 225-261

Cassis Y 2010 Capitals of capital: the rise and fall of international financial centres 1780-2009 Cambridge University Press, Cambridge

Chen X \& Cheung Y.-W 2011 Renminbi Going Global. China \& World Economy 19 118

Christophers B 2014 The territorial fix: Price, power and profit in the geographies of markets Progress in Human Geography 38 754-770 
Choi S R, Park D and Tschoegel A 2003 Banks and the worlds major banking centers, 2000 Review of world economics 139 550-568

Clifford Chance 2012 Renminbi Internationalisation - the London perspective Clifford Chance Briefing Note

City of London/Bourse Consult 2014 London RMB business volumes January- June 2014. City of London renminbi series. Policy practitioners paper, City of London corporation

Clark G L \& O'Connor K 1997 The informational content of financial products and the spatial structure of the global finance industry. In K. Cox (Ed.), Space of Globalization (pp. 89-114). New York: Guildford Press

Clark G L, Lai K. P. Y., \& Wójcik, D. 2015 Editorial introduction to the special section: deconstructing offshore finance Economic Geography 91 237-249

Cohen B J 2012 The yuan tomorrow? Evaluating China' currency internationalisation strategy New Political Economy 17 361-371

Cohen B J 2015 Currency power: understanding monetary rivalry. Princeton: Princeton University Press, Princeton

Deutsche Bank 2014 At the centre of RMB internationalisation: a brief guide to offshore RMB

Dicken P 1994 Global-local tensions: firms and states in the global space-economy. Economic Geography 70 101-28

Dicken P \& Malmberg 2001 Firms in Territories: A Relational Perspective. Economic Geography 77 345-363. 
Dicken P, Kelly P F, Olds K, \& Wai-Chung Yeung, H. 2001 Chains and networks, territories and scales: towards a relational framework for analysing the global economy Global Networks $189-112$

Dobson W and Masson P 2009 Will the renminbi become a world currency? China Economic Review 20 124-135

Eichengreen B \& Kawai M 2014 Issues for Renminbi internationalization: an overview. Asian Development Bank Institute 454

Eichengreen B 2012 Exorbitant privilege: the rise and fall of the dollar. Oxford: Oxford University Press, Oxford

Elden S 2005 Missing the point: globalization, deterritorialization and the space of the world. Transactions of the Institute of British Geographers 30 8-19

Elden S 2010 Land, terrain, territory. Progress in Human Geography 34 799-815

Faulconbridge J R 2004 London and Frankfurt in Europe's evolving financial centre network Area 36 235-44

Faulconbridge J, Engelen, E, Hoyler, M, \& Beaverstock J 2007 Analysing the changing landscape of European financial centres: The role of financial products and the case of Amsterdam Growth and Change 38 279-303.

Financial Times 2015a Chinese financial institutions grow closer to hear to London Financial Times 19 October 2015

Financial Times 2015b George Osborne's four lords push for stronger UK-China ties Financial Times 21 October 2015 http://www.ft.com/cms/s/0/ae5a6ed4-77eb11e5-a95a-27d368e1ddf7.html\#axzz4LMiOVwYl, accessed 26/9/16 
FSTIB 2014 London: the western hub for RMB, Financial Services Trade and Investment Board, retrieved from https://www.fstib.com/campaigns/rmbtrading/ 27/1/15

Fung H-G and Yau J 2012 Chinese offshore RMB currency and bon markets: the role of Hong Kong China and World Economy 20 107-122

The Guardian 2015 David Cameron dismisses risk of rift with US over China 18 October 2015 https://www.theguardian.com/world/2015/oct/18/davidcameron-dismisses-risk-of-rift-with-us-over-china, accessed 26/09/16

Haberly D and Wójcik D 2015 Tax havens and the production of offshore FDI: an empirical analysis Journal of Economic Geography 15 75-101

Hall S 2009 Financialised elites and the changing nature of finance capitalism: investment bankers in London's financial district Competition and Change 13 $173-189$

Hall S 2011 Geographies of money and finance I: Cultural economy, politics and place Progress in Human Geography 35 234-245

Hall S 2015 Banking with Chinese characteristics: Chinese financial elites in London's financial district, paper presented at Society for the Advancement of SocioEconomics Annual Conference, London, 2-4 July 2015.

Harvey D 1982 The Limits to Capital Verso

Held D and McGrew A 2002 Governing globalisation: power, authority and global governance. Polity Press.

He D \& McCauley R 2010 Offshore markets for the domestic currency: monetary and financial stability issues BIS Working Papers, No 320 
HKMA 2013 Press release - Third meeting of Hong Kong - London RMB forum retrieved from http://www.hkma.gov.hk/eng/key-information/pressreleases/2013/20130926-3.shtml, 28/1/15

HSBC 2013 Overview of RMB internationalisation, retrieved from https://www.hsbc.com.tr/eng/corporate_sme_banking/businesswithchina/_p df/RMB_Internatinoalisation_Turkey_Corp_v2.pdf, 27/1/15

Hudson A 1998 Reshaping the regulatory landscape: border skirmishes around the Bahamas and Cayman offshore financial centres. Review of International Political Economy 5 534-564

ICBC London 2013 Report and Financial Statements 2013 International Monetary Fund (IMF) (2015). 'IMF's Executive Board Includes Chinese Renminbi', IMF, 30 November, https://www.imf.org/external/np/sec/pr/2015/pr15540.htm (accessed 2 December 2015).

Kynaston D 2012 City of London: the history Vantage Books, London Lai K P Y 2011 Marketization through contestation: reconfiguring China's financial markets through knowledge networks Journal of Economic Geography, 11 87117

Lai K 2012 Differentiated Markets: Shanghai, Beijing and Hong Kong in China's Financial Centre Network Urban Studies 49 1275-1296

Lee J W 2014 Will the renminbi emerge as an international reserve currency? The world economy $3742-62$

Leyshon A 1992 The transformation of regulatory order: regulation in the global economy and environment Geoforum, 23, 249-267 
Leyshon A \& Tickell A 1994 Money order? The discursive construction of Bretton Woods and the making and breaking of regulatory space. Environment and Planning A 26 1861-1890

Leyshon A \& Thrift N 1997 Money/space: geographies of monetary transformation Routledge, London

Li R 2014 Offshore RMB market update, Bank of China HK

Luo Y and Tung R L 2007 International expansion of emerging market enterprises: A springboard perspective Journal of International Business Studies 38481-498 Moore E and Noble J 2014 UK takes first order for debut renminbi bond, Financial Times, retrieved from http://www.ft.com/cms/s/8d157620-5388-11e4-929b00144feab7de,Authorised=false.html?___location=http\%3A\%2F\%2Fwww.ft.co m\%2Fcms\%2Fs\%2F0\%2F8d157620-5388-11e4-929b-

00144feab7de.html\%3Fsiteedition\%3Duk\&siteedition=uk\&_i_referer=\#axzz3P GIA5byy 28/1/15

O'Brien R 1991 Global Financial Integration: the End of Geography. London: Pinter, 1991.

Palan R 2006 The offshore world: sovereign markets, virtual places and nomad millionaires Cornell University Press

People's Bank of China Study Group 2006 The Timing, Path, and Strategies of RMB Internationalization China Finance 5 12-13.

Pike A \& Pollard J 2010 Economic Geographies of Financialization. Economic Geography 86 29-51

Porteous D 1999. The development of financial centres: Location, information externalities and path dependency. In Money and the space economy, ed. R. Martin, 
95-114. Chichester: Wiley.

Reuters 2015. Beijing's stock rescue has $\$ 800$ billion bark, small market bite, 23 July, available at: http://uk.reuters.com/article/uk-china-markets-rescueidUKKCNOPXOAU20150723

Roberts S 1995 Small place, big money: The Cayman Islands and the international financial system Economic Geography, 3 237-256

Sassen, S. 2000. Cities in a world economy, 2nd ed. Thousand Oaks: Pine Forge Press.

Sassen S 2008 Territory, authority, rights Princeton University Press, Princeton

Schenk C 1998 The origins of the Eurodollar markets in London: 1955-1963 Explorations in economic history 35 221-238

Scott A J 1998 Regions and the world economy: the coming shape of global production, competition and political order Cambridge University Press, Cambridge

Sharman J C 2012 Chinese capital flows and offshore financial centers The Pacific Review 25 317-337

South China Morning Post 2016 'Brexit could dull London's sheen as offshore yuan centre' 19 June 2016 http://www.scmp.com/business/markets/article/1976870/brexit-could-dulllondons-sheen-offshore-yuan-centre, accessed 26 September 2016

Standard Chartered 2014 Offshore Renminbi: bonds outlook for 2014

Storper M 1997 The regional world: territorial development in a global economy. New York: Guildford. 
Storper M \& Venables A J 2004 Buzz: face-to-face contact and the urban economy Journal of Economic Geography 4 351-370

Strange S 1988 States and markets Pinter

Strauss D 2014 Financial centres vie for a slice of renminbi's growing offshore business Financial Times 30/09/14, retrieved from http://www.ft.com/cms/s/0/2485802e-2ea2-11e4-afe400144feabdc0.html\#axzz3PTUCj54e, 21/1/15

Swift 2011 RMB internationalisation: implications for the global financial industry. SWIFT RMB business insights report Swift, Belgium

Subacchi P 2010 "One currency, two systems": China's Renminbi strategy Chatham House Briefing Paper: International Economics

Subacchi P \& Huang H 2012 The connecting dots of China's Renminbi Strategy: London and Hong Kong. Retrieved August 20, 2014, from http://www.chathamhouse.org/sites/files/chathamhouse/public/Research/Int ernational Economics/0912bp_subacchi_huang.pdf

Society for Worldwide Interbank Financial Telecommunication (SWIFT) (2014). Singapore overtakes London as top RMB offshore clearing centre after Hong Kong. SWIFT, 28 April, https://www.swift.com/insights/pressreleases/singapore-overtakes-london-as-top-rmb-offshore-clearing-centreafter-hong-kong (accessed 18 January 2016).

The Economist 2015 The Osborne Doctrine 26 September 2015 http://www.economist.com/news/britain/21667935-britain-sleepwalkingmuch-closer-relationship-china-osborne-doctrine, accessed 27/09/16 
Thrift N 1994 On the social and cultural determinants of international financial centres: the case of the City of London In Corbridge S, Thrift $\mathrm{N}$ and Martin $\mathrm{R}$ Eds Money, Power and Space

Thrift N A \& Leyshon A 1994 A phantom state? The de-traditionalization of money, the international financial system and international financial centres Political Geography 13 299-327

Tickell A 2000 Dangerous derivatives: controlling and creating risks in international money Geoforum 31 87-99

Tschoegl A E 2000 International Banking Centers, Geography, and Foreign Banks. Financial Markets, Institutions and Instruments 9 1-32

Van Meeteren M \& Bassens D 2016 World Cities and the Uneven Geographies of Financialization: Unveiling Stratification and Hierarchy in the World City Archipelago International Journal of Urban and Regional Research 40 62-81

Walter C E and Howie F JT 2011 Red capitalism: the fragile financial foundation of China's extraordinary rise John Wiley and Sons, Singapore

Wójcik D \& Camilleri J 2015 Capitalist tools in socialist hands"? China Mobile in global financial networks Transactions of the Institute of British Geographers $40464-478$

Wójcik D 2013 Where governance fails: Advanced business services and the offshore world. Progress in Human Geography 37 330-347.

Wójcik D, MacDonald-Korth, D and Zhao, S X 2016 The political-economic geography of foreign exchange trading Journal of Economic Geography. doi: $10.1093 / \mathrm{jeg} / \mathrm{lbw} 014$ 
Yeung H W 2005 Rethinking relational economic geography. Transactions of the Institute of British Geographers 30 37-51.

Yeung H W and Liu W 2008 Globalizing China: the rise of Mainland firms in the global economy Eurasian Geography and Economics 49 57-86

Yeung H W-C, \& Coe, N M 2015 Towards a dynamic theory of global production networks Economic Geography 91 29-58

Ying H 2013 China's banks in London. Retrieved from http://csfi.org/files/chinabanklondonfinal.pdf

Zhang M 2009 China's New International Financial Strategy amid the Global Financial Crisis China \& World Economy 17 22-35

Z/Yen 2016 The Global Financial Centres Index 20 
Table 1 Attributes of leading offshore RMB centres

\begin{tabular}{|c|c|c|c|c|}
\hline $\begin{array}{l}\text { Financial } \\
\text { services } \\
\text { activity }\end{array}$ & Hong Kong & Singapore & Taiwan & London \\
\hline $\begin{array}{l}\text { RMB deposits } \\
\text { (RMB bn) }\end{array}$ & 827 & 172 & 123 & 15 \\
\hline $\begin{array}{l}\text { Clearing Bank } \\
\text { RQFIl quota } \\
\text { (RMB bn), } \\
\text { (date of initial } \\
\text { allocation) }\end{array}$ & $\begin{array}{l}\text { BOC HK } \\
270 \\
(2011)\end{array}$ & $\begin{array}{l}\text { ICBC SG } \\
50 \\
(2013)\end{array}$ & $\begin{array}{l}\text { BOC TW } \\
100 \\
\text { (proposed) }\end{array}$ & $\begin{array}{l}\text { China Construction Bank } \\
80 \\
(2014)\end{array}$ \\
\hline RMB services & $\begin{array}{l}\text { Retail and commercial banking } \\
\text { Foreign Exchange } \\
\text { Primary and secondary RMB securities } \\
\text { market } \\
\text { RMB trade facilitation }\end{array}$ & $\begin{array}{l}\text { Retail and commercial banking } \\
\text { Foreign Exchange } \\
\text { Broad financial market products } \\
\text { RMB trade facilitation }\end{array}$ & $\begin{array}{l}\text { Retail and commercial banking } \\
\text { Limited financial market } \\
\text { products } \\
\text { RMB trade facilitation }\end{array}$ & $\begin{array}{l}\text { Foreign exchange } \\
\text { Limited financial market products } \\
\text { Limited retail and commercial } \\
\text { banking }\end{array}$ \\
\hline $\begin{array}{l}\text { Key } \\
\text { advantages }\end{array}$ & $\begin{array}{l}\text { Gateway to mainland Chinese markets } \\
\text { Strong existing financial centre } \\
\text { infrastructure }\end{array}$ & $\begin{array}{l}\text { ASEAN financial hub } \\
\text { Strong existing financial centre } \\
\text { infrastructure } \\
\text { Hub for regional treasury and } \\
\text { commodity traders } \\
\text { Strong asset management market } \\
\text { with wide investor pool }\end{array}$ & $\begin{array}{l}\text { Strong trade links } \\
\text { Large deposit base with need to } \\
\text { cross border remittances }\end{array}$ & $\begin{array}{l}\text { European time zone } \\
\text { World's leading foreign exchange } \\
\text { centre } \\
\text { Strong existing financial } \\
\text { infrastructure }\end{array}$ \\
\hline Focus markets & $\begin{array}{l}\text { Greater China regional treasury centre } \\
\text { Pilot schemes and new product } \\
\text { development }\end{array}$ & $\begin{array}{l}\text { South Asia Regional Trade Centre } \\
\text { Commodities centre } \\
\text { Private banking }\end{array}$ & $\begin{array}{l}\text { Domestic/Cross-strait RMB } \\
\text { usage }\end{array}$ & $\begin{array}{l}\text { Global treasury centre, global } \\
\text { foreign exchange trading, asset } \\
\text { management }\end{array}$ \\
\hline
\end{tabular}


Figure 1 Monetary form, geographical reach and policy basis of RMB internationalisation
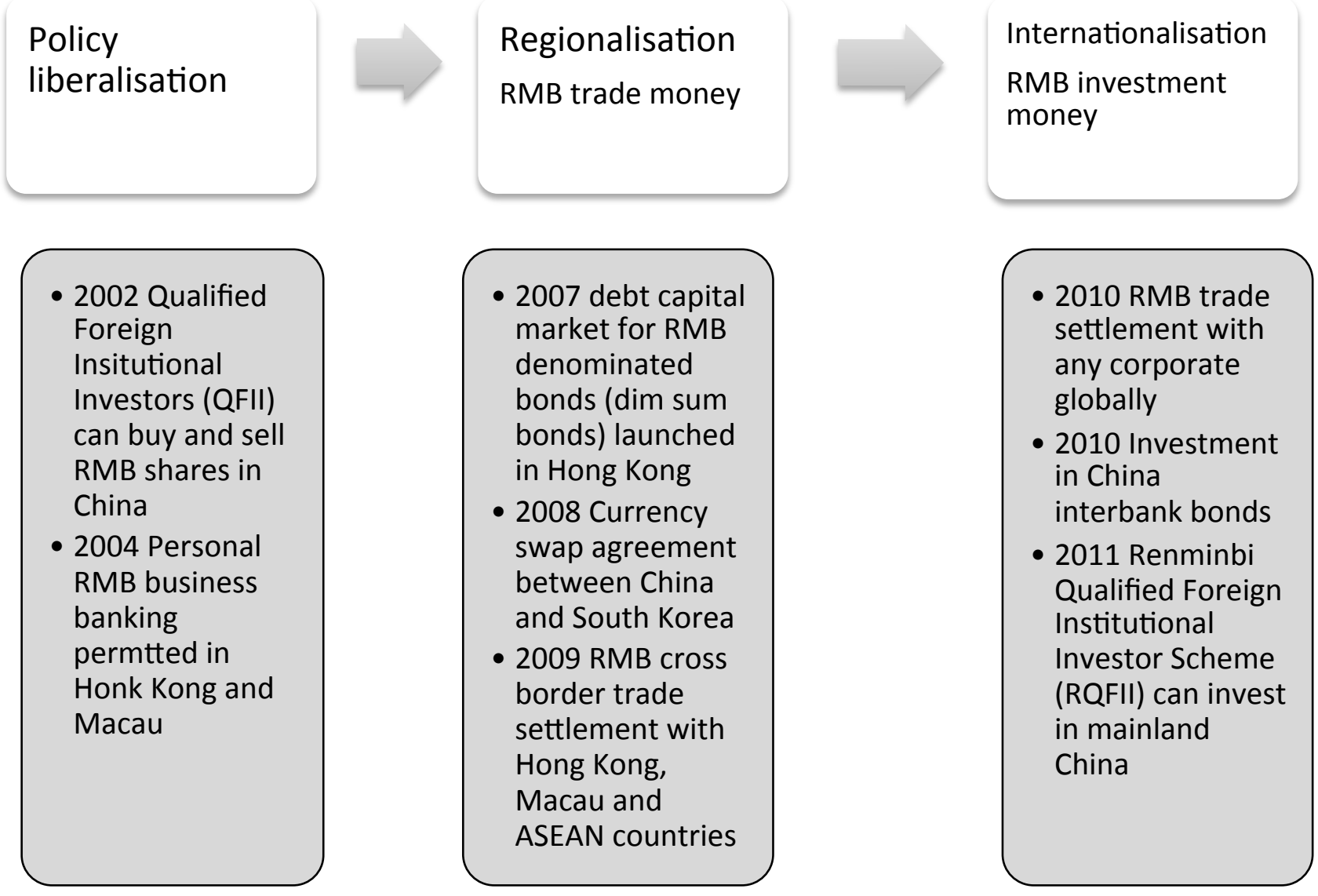
Network of offshore
RMB centres

Diversification of

RMB monetary

forms

- 2007 debt capital market for RMB

denominated bonds (dim sum bonds) launched in Hong Kong

- 2008 Currency swap agreement between China and South Korea

- 2009 RMB cross border trade settlement with Hong Kong,

Macau and ASEAN countries
- 2010 RMB trade settlement with any corporate globally

- 2010 Investment in China interbank bonds

- 2011 Renminbi Qualified Foreign Institutional Investor Scheme (RQFII) can invest in mainland China
- Development of dim sum bond market beyond Hong Kong (London, 2012)

- 2013 London given initial RMB quota of 80bn RMB

- 2014 China Construction Bank named as RMB clearing bank in London

Source: adapted from Swift 2011 using author's research 
Figure 2 Timeline of London's development as an offshore RMB centre

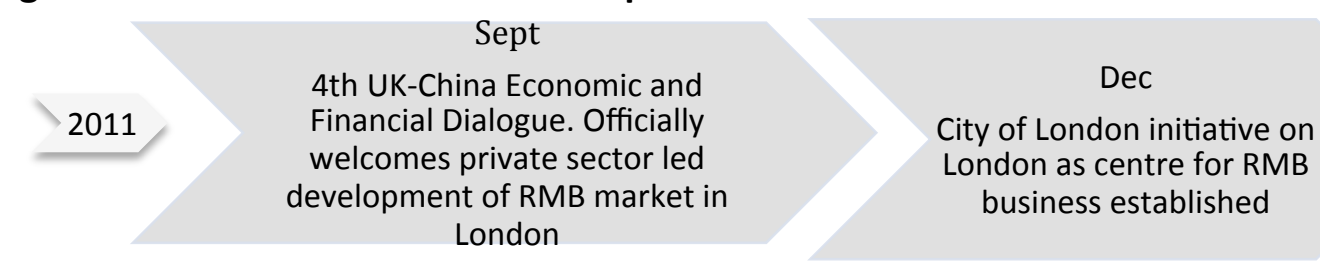

$\begin{array}{lc}\text { Jan } & \text { April } \\ 2012 & \text { UK Chancellor and Chief executive } \\ \text { of Hong Kong Monetary Authority } & \text { First RMB bond issuance outside } \\ \text { announce co-operation of offshore } & \text { Hong Kong and mainland China by } \\ \text { RMB business } & \text { HSBC in London }\end{array}$

\section{Oct}
$5^{\text {th }}$ UK-China Economic and Financial Dialogue. Chinese bank
branch applications to be
considered in UK. London given RMB80Bn RQFII quota

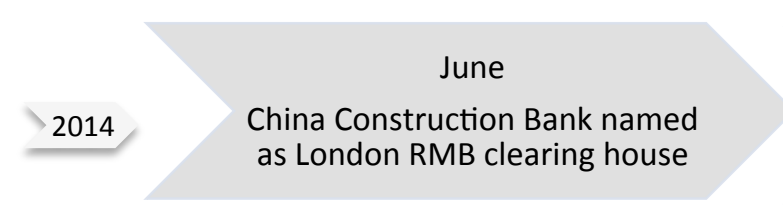

\section{Oct}

UK Government issued RMB bond on LSE. First non Chinese issuance of sovereign RMB debt

\section{Dec}

ICBC first mainland Chinese bank to obtain PRA banking license

Source: adapted from Ying (2013: 12-13) using author's research 
Table 2: Factors accounting for the identification of London as the first western offshore RMB centre

\begin{tabular}{|c|c|c|}
\hline Institutional form & Specific attribute & Indicative example from research interviews \\
\hline \multirow[t]{3}{*}{$\begin{array}{l}\text { City specific } \\
\text { conventions }\end{array}$} & $\begin{array}{l}\text { Propensity for financial market } \\
\text { innovation }\end{array}$ & $\begin{array}{l}\text { "There was definitely a period in the } 2010 \text { s when the City [of London] needed to think about new } \\
\text { markets to try to cement its position as the leading financial centre - there was interest in carbon } \\
\text { markets for example but RMB finance was also definitely identified as an option which had strong } \\
\text { Government support" } \\
\text { (Capital markets lawyer, London, March 2015) }\end{array}$ \\
\hline & International outlook & $\begin{array}{l}\text { "London is an international centre in ways that places like New York and even Singapore aren't } \\
\text { really. You can see this in its pre-eminence in foreign exchange trading, but in less clear measures } \\
\text { like its outlook, the international origin of the financial institutions here and the backgrounds of } \\
\text { the people working here. That makes it an obvious destination for RMB markets" } \\
\text { (Vice president, Chinese commercial bank, London, June 2015) }\end{array}$ \\
\hline & $\begin{array}{l}\text { Relational proximity between } \\
\text { China and the UK }\end{array}$ & $\begin{array}{l}\text { "London has particular advantages that make it the obvious choice for an RMB hub in Europe. It is } \\
\text { obviously the leading financial centre in the region, but its location makes working with Beijing } \\
\text { easier, it has close links with Hong Kong and Beijing that can be drawn upon to build successful } \\
\text { RMB markets and it has the specific experience of developing offshore [euro-dollar] markets" } \\
\text { (Banking Associate, Chinese commercial banks, Beijing December 2014) }\end{array}$ \\
\hline $\begin{array}{l}\text { External economies } \\
\text { of scale available to } \\
\text { financial institutions } \\
\text { in London }\end{array}$ & $\begin{array}{l}\text { Market Liquidity and } \\
\text { associated labour market } \\
\text { expertise }\end{array}$ & $\begin{array}{l}\text { "The depth of the market in London and the associated expertise in developing new markets, from } \\
\text { financiers and lawyers makes London an obvious choice (to develop RMB markets) compared to } \\
\text { other centres" } \\
\text { (Bank vice president, Chinese Commercial bank, London, February 2015) }\end{array}$ \\
\hline $\begin{array}{l}\text { Regulatory } \\
\text { environment }\end{array}$ & $\begin{array}{l}\text { Comparatively deregulated, } \\
\text { flexible financial milieu }\end{array}$ & $\begin{array}{l}\text { "The development of the euro dollar market in London [in the 1960s] demonstrates that the City is } \\
\text { prepared to use favourable regulation to stimulate new markets and that is certainly attractive to } \\
\text { the Chinese monetary authorities" } \\
\text { (Financial journalist, China desk, London, March 2015) }\end{array}$ \\
\hline
\end{tabular}

Source: Author's fieldwork 